\title{
$\mathrm{A}^{\mathrm{R}} \mathrm{I} \mathrm{LS}$ \\ UK \& Ireland \\ Art Libraries Society \\ OCCASIONAL PUBLICATIONS
}

\section{CURRENT TITLES}

- Artists' books: a cataloguers' manual (2006)

Compiled by Maria White, Patrick Perratt and Liz Lawes for the ARLIS/UK \& Ireland Cataloguing and Classification Committee

This manual is designed for anyone involved in the cataloguing of artists' books, and takes the cataloguer through each applicable rule from AACR2. The appendices include full examples in MARC 21 and a bibliography.

ISBN $0955244501(9780955244506)$

$£ 35$ for members ( $£ 45$ for non-members)

- First steps in archives: a practical guide (2004)

Compiled by the ARLISNUK \& Ireland Visual Archives Committee

This straightforward introduction to the key principles of archive work is designed for anyone whose collections include archive material, but who has no formal training in this area.

ISBN 0951967495

$£ 25$ to members ( $£ 30$ to non-members)

- Art exhibition documentation in libraries: cataloguing guidelines (2000)

Compiled by the ARLIS/UK \& Ireland Cataloguing and Classification Committee

An invaluable addition to the professional literature for cataloguers interested in standards and data sharing.

ISBN 0951967479

$£ 30$ to members ( $£ 35$ to non-members)

\section{COMING SOON!}

- Displays and exhibitions in libraries (June 2009)

Edited by Christine Milne \& Annamarie McKie for the ARLIS/UK \& Ireland Publications Committee

Based on the experiences of ARLIS members, this illustrated publication will look at key areas of exhibition creation in a library context from planning to promotion, finance to feedback. Of use to all librarians who wish to make more of their library's resources and facilities.

\section{All orders and correspondence to:}

ARLIS/UK \& Ireland Business Manager, Word \& Image Department, Victoria \& Albert Museum, London SW7 2RL, UK; Tel: +44 (0) 207942 2317, email: arlis@vam.ac.uk

Cheques should be made payable to ARLIS/UK \& IRELAND either in $₹$ sterling or in US dollars. Prices include surface mail postage; airmail supplement on request. 


\section{Picasso's \\ Paintings, Watercolors, Drawings and Sculpture A Comprehensive Illustrated Catalogue 1885-1973}

This series of catalogues, directed by the late Herschel Chipp and Alan Hyman, is the most comprehensive on the master's work yet published.

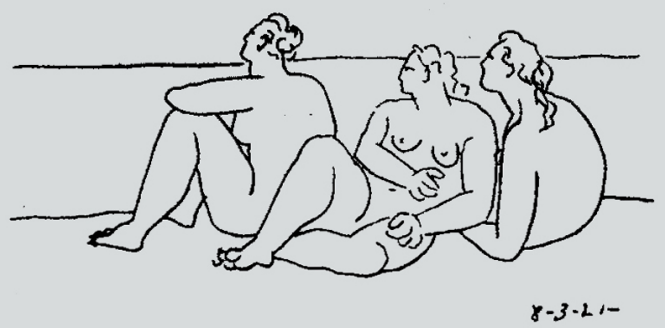

The first catalogues appeared in 1995 and there will soon be 22 volumes covering 78 years of Picasso's 91 year lifespan. Subsequent catalogues will complete the project. Each volume contains an overview introduction and a chronology of the period. Each entry contains titles in English and French (Spanish and Catalan for the early years); date and place of creation, when known; dimensions of the work; location of the collection which owns the work, if public; selected publications in which the work has been illustrated; a bibliography of works that are cited; and concordances to Zervos, the Musée Picasso, Paris, the Museu Picasso, Barcelona and other standard reference works. There are also citations of sales of works from selected auctions.

$\begin{array}{llll}\text { Volume Title } & \text { Years } & \text { ISBN } & \text { Publication Date } \\ \text { Youth in Spain I } & 1885-1897 & 1-55660-321-5 & 2008 \\ \text { Youth in Spain II } & 1897-1900 & 1-55660-322-3 & 2008 \\ \text { Turn of the Century } & 1900-1902 & 1-55660-323-1 & 2009 \\ \text { [Forthcoming Volumes] } & 1903-1916 & & \\ \text { From Cubism to Neoclassicism } & 1917-1919 & 1-55660-230-8 & 1995 \\ \text { Neoclassicism I } & 1920-1921 & 1-55660-231-6 & 1995 \\ \text { Neoclassicism II } & 1922-1924 & 1-55660-232-4 & 1996 \\ \text { Toward Surrealism } & 1925-1929 & 1-55660-233-2 & 1996 \\ \text { Surrealism } & 1930-1936 & 1-55660-234-0 & 1997-\text { Revised 2009 } \\ \text { Spanish Civil War } & 1937-1939 & 1-55660-262-6 & 1997 \\ \text { Europe at War } & 1939-1940 & 1-55660-235-9 & 1998 \\ \text { Nazi Occupation } & 1940-1944 & 1-55660-236-7 & 1999 \\ \text { Liberation and Post-War Years } & 1944-1949 & 1-55660-237-5 & 2000 \\ \text { The Fifties I } & 1950-1955 & 1-55660-301-0 & 2000 \\ \text { The Fifties II } & 1956-1959 & 1-55660-302-9 & 2000 \\ \text { The Sixties I } & 1960-1963 & 1-55660-303-7 & 2001 \\ \text { The Sixties II } & 1964-1967 & 1-55660-304-5 & 2002 \\ \text { The Sixties III } & 1965-1969 & 1-55660-313-4 & 2002 \\ \text { The Final Years } & 1970-1973 & 1-55660-305-3 & 2003 \\ & & & \\ \text { THE GRAPHIC WORK (Revised Bloch and Mourlot) } & & 2009 \\ \text { The Printed Graphic Work } & 1966-1969 & 1-55660-315-0 & 2004 \\ \text { The Printed Graphic Work } & 1970-1972 & 1-55660-316-9 & 2004 \\ \text { The Lithographic Work I } & 1919-1949 & 1-55660-324-X & 2009 \\ \text { The Lithographic Work II } & 1949-1969 & 1-55660-325-8 & 2009 \\ \end{array}$

\section{Alan Wofsy Fine Arts, San Francisco - www.art-books.com - order@art-books.com}

